\title{
Varsling av avvik - en vanskelig balansekunst
}

\author{
Hensikten med å varsle om avvik er ikke å peke ut syndebukker, men å øke pasientsikkerheten. Likevel \\ unnlater mange å melde fra om uønskete hendelser, viser en undersøkelse.
}

\section{FORFATTERE}

Ingeborg Ulvund

-Høgskolelektor

Avd. for helse- og sosialfag, Høgskolen i Molde

Anne-Marie Mork Rokstad

Førsteamanuensis II

Avd. for helse- og sosialfag, Høgskolen i Molde

\section{Solfrid Vatne}

Professor

Avd. for helse- og sosialfag, Høgskolen i Molde

\section{SAMMENDRAG}

Bakgrunn: Helsemyndighetene forventer at avvik meldes. Likevel viser forskning at avvik underrapporteres, og det diskuteres hvorfor. Det er behov for kunnskap om faktorer som fremmer og hemmer avviksrapportering i helsetjenesten.

Hensikt: Studien tar sikte på å beskrive faktorer som påvirker jordmødres og psykiatriske sykepleieres varsling av avvik.

Metode: Studien har et kvantitativt design. Vi samlet inn data ved å bruke et egenutfylt spørreskjema. Utvalget består av jordmødre og psykiatriske sykepleiere $(n=133)$.

Resultat: De fleste kjente til prosedyrer for avvikshåndtering på egen arbeidsplass, men flere kjente til prosedyrer for varsling av kliniske feil enn for uetisk praksis. Den viktigste grunnen til å varsle var å hindre at pasienter skades. Før de varslet, vurderte mange også om varslingen kunne bli en belastning for dem selv eller en kollega.

Konklusjon: Tendensen var at jordmødre og psykiatriske sykepleiere prioriterte pasientens rettigheter høyt. Varsling av avvik utløste kompliserte vurderinger som ble påvirket av kulturelle og organisatoriske forhold. 
skal brukes til å forebygge at uønskete hendelser gjentar seg, og det legges vekt på at meldingene skal medvirke til læring. For at organisasjoner skal lære av avvik, er det en forutsetning at de har kjennskap til avvikene som forekommer.

Forskning viser at avvik underrapporteres, og at helsetjenesten mangler kunnskap om hvorfor helsepersonell unnlater å varsle dem. Sykepleiere er sentrale aktører i

helsetjenesten. Det er derfor viktig å ha kunnskap om deres holdninger til og erfaringer med varsling av avvik når helsetjenesten skal innfri regjeringens forventning om system og kulturer for læring av feil (4).

\section{OPPMERKSOMHET PÅ PASIENTSIKKERHET}

Spesialisthelsetjenesteloven § 3-3, § 3-3a og §4 (5) og internkontrollforskriften (6) pålegger spesialisthelsetjenesten å ha meldesystem og rutiner for oppfølging av avvik. De er også pålagt å gi tilsynsmyndighetene (Kunnskapssenteret og Helsetilsynet) informasjon om forhold som har eller kunne ha medført fare for pasienters sikkerhet $(5,6)$. I tråd med dette blir sykepleiere motivert til å ha oppmerksomhet på pasientsikkerhet gjennom utdanning og yrkesetiske retningslinjer. I punkt 5.4 i Yrkesetiske retningslinjer for sykepleiere står det følgende: «Sykepleieren melder fra eller varsler når pasienter utsettes for kritikkverdige eller uforsvarlige forhold. Lojalitet til arbeidsstedet skal ikke hindre dette.» (7).

Selv om pasientsikkerhet har stått høyt på agendaen i flere tiår, er forskningsfeltet relativt nytt. Gode begreper og definisjoner er under utvikling. En definisjon av pasientsikkerhet er denne: «Pasienter skal ikke utsettes for un $\varnothing$ dig skade eller risiko for skade som følge av helsetjenestens innsats og ytelser eller mangel på det samme.» $(8$, s. 6).

\section{«Det er vanskelig å varsle avvik gjort av en kollega.»}

Begrepene «uønsket hendelse», «avvik», «feil», «kritikkverdig forhold» og «mangelfull» eller «uforsvarlig praksis» brukes om hendelser der pasienten er i fare for å bli skadet eller blir skadet (8). Ord som «varsle», «rapportere» og «(avviks)melde» brukes om handlingen som fører til at avvik avsløres. I denne artikkelen bruker vi begrepet «avvik» på en slik måte at det omfatter skade og fare for å skade pasienten. Begrepet «varsle» bruker vi om det å melde hendelsen til noen som har myndighet til å gjøre noe med den.

\section{TIDLIGERE FORSKNING}

Forskning viser at sykepleiere kontinuerlig og aktivt involverer seg i pasientsikkerhetsarbeid. De forventer, både av seg selv og andre, at de er pasientens talsperson som skal varsle om avvik (9-11). Samtidig kommer det fram at varsling av avvik kan utløse formelle og/eller uformelle sanksjoner som for eksempel gjengjeldelse, utestengelse fra kollegiet, fortielse, tap av avansementsmuligheter eller endret ansettelsesforhold (12-18). Det rapporteres at både formelle og uformelle sanksjoner har ført til fysisk, psykisk og/eller sosialt stress, med påfølgende redusert helse- og arbeidsevne (14-18).

Valget mellom å varsle eller å la være påvirkes av forhold både på individ- og systemnivå. Det kan for eksempel være manglende kjennskap til melderutiner, lav konsensus om hva som skal meldes, erfaring med at varsling ikke fører til at noe blir gjort, og mangelfull st $\varnothing$ tte i arbeidsmiljøet $(14-17,19)$. Det etterlyses forskning på psykososiale følger for dem som forårsaker avvik og forhold som fremmer og hemmer varsling (16-19). Hensikten med dette prosjektet var å beskrive faktorer som påvirker jordmødres og psykiatriske sykepleieres varsling av avvik.

\section{METODE}


Denne studien er en del av et forskningsprosjekt som ble gjennomført i et samarbeid mellom sykepleieforskere ved Høgskolen i Molde og James Cook University i Australia. Vi anvendte både kvantitativ og kvalitativ metode (20). Her presenterer vi resultatet fra den norske kvantitative spørreundersøkelsen.

\section{UTVALG OG REKRUTTERING}

Inklusjonskriteriet var gyldig autorisasjon eller godkjennelse som psykiatrisk sykepleier eller jordmor. Disse to gruppene var spesialsykepleiere som forskerteamet hadde kunnskap om. I tillegg vurderte vi det som at de hadde sammenliknbar yrkesfunksjon og selvstendighet $i$ egen yrkesut $\varnothing$ velse både i Norge og Australia.

Vi rekrutterte informantene fra spesialisthelsetjenesten, fra føde-/barselenheter og psykiatriske enheter ved ti sykehus spredt over hele Norge. Lederen av organisasjonene informerte ansatte om studien og delte ut informasjonsskriv og spørreskjema. Det var valgfritt å besvare spørreskjemaet online, gjennom en webadresse eller på en papirversjon med medfølgende adressert og frankert svarkonvolutt. For at det skulle være praktisk mulig å gjennomføre spørreunders $\emptyset$ kelsen, ble det ikke innhentet data om hvor mange som ble invitert til å delta. Derfor har vi ikke regnet ut svarprosent.

\section{DATAINNSAMLING}

Forskerne fra Norge og Australia samarbeidet om å utvikle spørreskjemaet. I tillegg innhentet vi tillatelse til å bruke deler av et spørreskjema vi hadde brukt tidligere, som er utviklet av Firth-Cozens, Firth og Booth $(20,21)$. Forskere som hadde lang klinisk erfaring, diskuterte seg fram til temaer det var viktig å utforske, og ble enige om sentrale begreper og innhold i spørsmålene. Spørsmålene ble formulert parallelt på australsk-engelsk og norsk. Vi brukte begrepene «klinisk praksis» og «uetisk praksis» for å skille mellom avvik knyttet til behandling i kliniske situasjoner, som for eksempel feilmedisinering, og avvik knyttet til uetiske handlinger.

\section{«Før de varslet, ville en fjerdedel vurdere faren for å miste jobben.»}

Vi prøvde først ut spørreskjemaet i en pilotstudie før det ble modifisert til bruk i hovedundersøkelsen. Spørreskjemaet hadde 31 spørsmål med til sammen 62 variabler og flere typer svaralternativer. Ti av spørsmålene kunne besvares med «ja», «nei» eller «vet ikke». Ett hadde Likert-skala med svaralternativene «svært vanskelig», «vanskelig», «nøytral», «lett» og «svært lett». To spørsmål hadde svaralternativene «svært viktig», «viktig», «uviktig» eller «helt uviktig». På ett spørsmål rangerte informantene svaralternativene fra første til femte prioritet. Manglende data (missing) overskred ikke 8 prosent på noen av spørsmålene.

\section{ETISKE OVERVEIELSER}

Forskerne erkjenner at dataene potensielt er av sensitiv karakter, og derfor ble konfidensialitet og anonymitet to ledende prinsipper i studien. Vi brukte et anonymt spørreskjema uten kodemerking og purremuligheter. Rådata inneholdt ikke navn på deltaker eller arbeidssted. Vi antok at ingen av deltakerne ville få problemer som følge av deltakelse i studien, men skulle dette skje, fikk deltakerne navn på medlemmer i forskningsgruppen som stilte til disposisjon. Forskerne var ikke ansatt og hadde ikke arbeidskollegaer $\mathrm{i}$ helseforetakene som deltakerne ble rekruttert fra. Informasjonsskrivet presiserte at deltakelsen i unders $\varnothing$ kelsen var frivillig. De som valgte å delta, samtykket da de returnerte det utfylte spørreskjemaet. Studien er godkjent av Norsk samfunnsvitenskapelig datatjeneste (NSD, nå Norsk senter for forskningsdata). 


\section{DATAANALYSE}

Dataene ble statistisk behandlet og analysert ved hjelp av IBM SPSS Statistics versjon 22 (Boston, USA). Vi brukte deskriptiv statistikk med frekvensanalyser, krysstabeller og sammenlikning av gjennomsnitt, sentraltendens og spredning for å få oversikt og beskrive sosiodemografiske data. Slutningsstatistikk med kjikvadrattest ble brukt for å unders $\varnothing$ ke sammenhenger mellom jordmødre og psykiatriske sykepleiere, og mellom de som hadde varslet, og de som ikke hadde varslet. Uavhengige variabler ble gjort dikotome.

Signifikansnivået ble satt til $p<0,05$.

\section{RESULTAT}

53 prosent (70) psykiatriske sykepleiere og 47 prosent (63) jordmødre svarte. Alle arbeidet $\mathrm{i}$ spesialisthelsetjenesten og var 23 år eller eldre $(n=133)$. Jordm $\varnothing$ drene hadde fra to til 34 års yrkeserfaring (median 12,8 år), og de psykiatriske sykepleierne fra ett til 40 år (median 10,6 år). Det var ikke signifikant sammenheng mellom profesjon og antall år med yrkeserfaring. Siden det bare var 18 menn som deltok, skiller vi ikke mellom kjønn i presentasjonen av funn. Vi bruker fellesbetegnelsen «spesialsykepleier» på jordmødre og psykiatriske sykepleiere.

\section{ERFARING MED VARSLING}

11,9 prosent (15) av informantene svarte at de hadde gitt feil medisin minst én gang de siste tolv månedene, mens 4,0 prosent (5) svarte at de hadde gitt feil behandling til en pasient $\mathrm{i}$ samme tidsrom ( $n=126)$. Av dem som hadde gitt feil medisin, svarte 20,0 prosent (3) at de hadde unnlatt å varsle. Alle som hadde gitt feil behandling, varslet.

Minst én gang hadde 65,4 prosent (87) av informantene vært vitne til en uønsket hendelse som andre hadde forårsaket. Det var ikke signifikant sammenheng mellom erfaring med avvik og profesjon. 50,6 prosent (44) varslet hendelsen, og 44,8 prosent (39) varslet ikke. Av dem som ikke varslet, svarte 76,9 prosent (30) at de burde ha gjort det, mens 11,4 prosent (5) av dem som hadde varslet, ikke ville ha varslet igjen. Det var signifikant flere psykiatriske sykepleiere, 37,3 prosent (31), enn jordmødre, 15,7 prosent (13), som hadde varslet $(p=$ $0,003)(n=83)$.

\section{KJENNSKAP TIL PROSEDYRER FOR VARSLING}

Når det gjaldt kjennskap til varslingsrutiner for kliniske feil, svarte 13,1 prosent (17) at arbeidsplassen ikke hadde, eller at de ikke visste om arbeidsplassen hadde, en prosedyre for dette. Det var ikke signifikant sammenheng mellom kjennskap til en slik prosedyre og profesjon. Det var imidlertid en signifikant forskjell mellom profesjonene når det gjaldt kjennskap til prosedyre for varsling av uetisk praksis mot pasient. Av dem som svarte at de ikke kjente til en slik prosedyre, var 37,0 prosent (48) jordmødre og 25,4 prosent (33) psykiatriske sykepleiere $(p=0,001)(n=130)$.

\section{PROSESSEN MED Å VARSLE}

Informantene svarte at det var vanskelig å varsle om avvik hos en kollega. Hele 67,7 prosent (90) svarte at det var vanskelig å varsle når den aktuelle kollegaen er sykepleier. 63,2 prosent (84) svarte at det var vanskelig å varsle når kollegaen ikke er sykepleier.

På spørsmålet om hvorfor det er viktig å varsle, ble det ikke skilt mellom egne avvik eller avvik andre hadde forårsaket. «Forbedring av praksis / minimalisering av skade» fikk høyest skår på rangeringen av hva som ble lagt til grunn for å varsle, men det var flere psykiatriske sykepleiere, 7,8 prosent (10), enn jordmødre, 1,6 prosent (2), som prioriterte dette som mindre viktig (tabell 1 ). 
Tabell 1: Spesialsykepleiernes vurdering av etiske verdiers betydning for hvorvidt de varsler eller ikke

\begin{tabular}{|c|c|c|c|c|c|}
\hline \multicolumn{6}{|c|}{ Viktig* n (\%) } \\
\hline & Jordmor & $\begin{array}{l}\text { Psykiatriske } \\
\text { sykepleiere }\end{array}$ & $\chi^{2}$ & $\mathrm{n}$ & Missing \\
\hline & $n=60$ & $n=69$ & p-verdi & & $\%$ \\
\hline $\begin{array}{l}\text { Forbedre praksis / minimal- } \\
\text { isere skade for pasient }\end{array}$ & $56(43,4)$ & $52(40,3)$ & 0,022 & 129 & 3,0 \\
\hline $\begin{array}{l}\text { Pasientens/brukerens } \\
\text { autonomi }\end{array}$ & $38(29,5)$ & $53(41,1)$ & 0,145 & 129 & 3,0 \\
\hline $\begin{array}{l}\text { Rettferdighet for bruker/ } \\
\text { pasient }\end{array}$ & $17(13,2)$ & $17(13,2)$ & 0,361 & 129 & 3,0 \\
\hline $\begin{array}{l}\text { Moralsk integritet for } \\
\text { pasient/bruker }\end{array}$ & $11(8,5)$ & $18(14,0)$ & 0,313 & 129 & 3,0 \\
\hline Fremme gjensidig respekt & $15(11,6)$ & $14(10,9)$ & $14(10,9) x$ & 129 & 3,0 \\
\hline
\end{tabular}

*Kategoriene svært viktig og viktig er slått sammen til viktig.

Informantene prioriterte mellom fem oppgitte faktorer da de svarte på hvilke hensyn som må ivaretas for at de skal varsle (tabell 2). Alle som svarte, 100 prosent (130), sa at det var viktig å holde «fokus på det som skjedde». 94,6 prosent (123) svarte at det var viktig at «retningslinjene først unders $\varnothing$ kes». 93,8 prosent (122) svarte at «situasjonen først diskuteres med den det gjelder» og 93,1 prosent (121) at det var viktig «ikke å ha en klandrende innstilling». Det som fikk lavest skår, var knyttet til ansvar for hendelsen: 81,4 prosent (105) mente det var viktig å plassere ansvaret, mens 18,0 prosent (23) svarte at det var viktig at «de involverte straffes». Det var ingen signifikante sammenhenger mellom profesjonene og de oppgitte faktorene $(n=130)$. Tabell 2 viser fordelingen mellom de som varslet, og de som hadde vurdert å varsle, men som ikke gjorde det.

Tabell 2: Spesialsykepleiernes vurdering av oppgitte faktorers betydning for hvorvidt de varsler eller ikke

\begin{tabular}{|c|c|c|c|c|c|}
\hline \multicolumn{6}{|c|}{ Viktig* n (\%) } \\
\hline & $\begin{array}{l}\text { Varslet } \\
n=44\end{array}$ & $\begin{array}{l}\text { Varslet ikke } \\
n=69\end{array}$ & $\begin{array}{l}\chi^{2} \\
\text { p-verdi }\end{array}$ & $n$ & \\
\hline & & & & & $\%$ \\
\hline $\begin{array}{l}\text { At det er fokus på det som } \\
\text { skjedde }\end{array}$ & $44(53,0)$ & $39(47,0)$ & $* *$ & 83 & 0 \\
\hline $\begin{array}{l}\text { At prosedyrene/ } \\
\text { retningslinjene undersøkes }\end{array}$ & $41(49,4)$ & $37(44,6)$ & 0,747 & 83 & 0 \\
\hline $\begin{array}{l}\text { At situasjonen først disku- } \\
\text { teres med den det gjelder }\end{array}$ & $41(49,4)$ & $36(43,4)$ & 0,878 & 83 & 0 \\
\hline $\begin{array}{l}\text { At man ikke har en klandren- } \\
\text { de innstilling }\end{array}$ & $40(48,2)$ & $34(41,0)$ & 0,585 & 83 & 0 \\
\hline At ansvaret plasseres & $35(42,7)$ & $27(32,9)$ & 0,372 & 82 & 1,3 \\
\hline At de involverte straffes & $7(8,6)$ & $4(4,9)$ & 0,505 & 81 & 2,5 \\
\hline
\end{tabular}

* Kategoriene svært viktig og viktig er slått sammen til viktig.

** Ingen statistikk beregnet fordi alle som svarte, svarte viktig.

Informantene tok stilling til 14 påstander og svarte på hvor stor betydning de hadde for hvorvidt de varslet eller ikke. Figur 1 viser hvordan det totale antallet informanter fordelte seg. Det var ingen signifikante sammenhenger mellom profesjon og den enkelte påstand. Da vi sammenliknet svarene fra dem som varslet sett i forhold til dem som ikke varslet, så vi to signifikante sammenhenger. 23,5 prosent (19) vurderte «ville ikke forårsake trøbbel» som viktig og varslet ikke, og 13,6 prosent (11) vurderte påstanden som viktig og varslet ( $p=$ $0,023)(n=81)$. Den andre signifikante sammenhengen var følgende: Av dem som vurderte «ikke å ha noen å diskutere saken med» som viktig, hadde 32,1 prosent (26) varslet og 39,5 prosent (32) ikke varslet $(p=0,018)(n=81)$. 


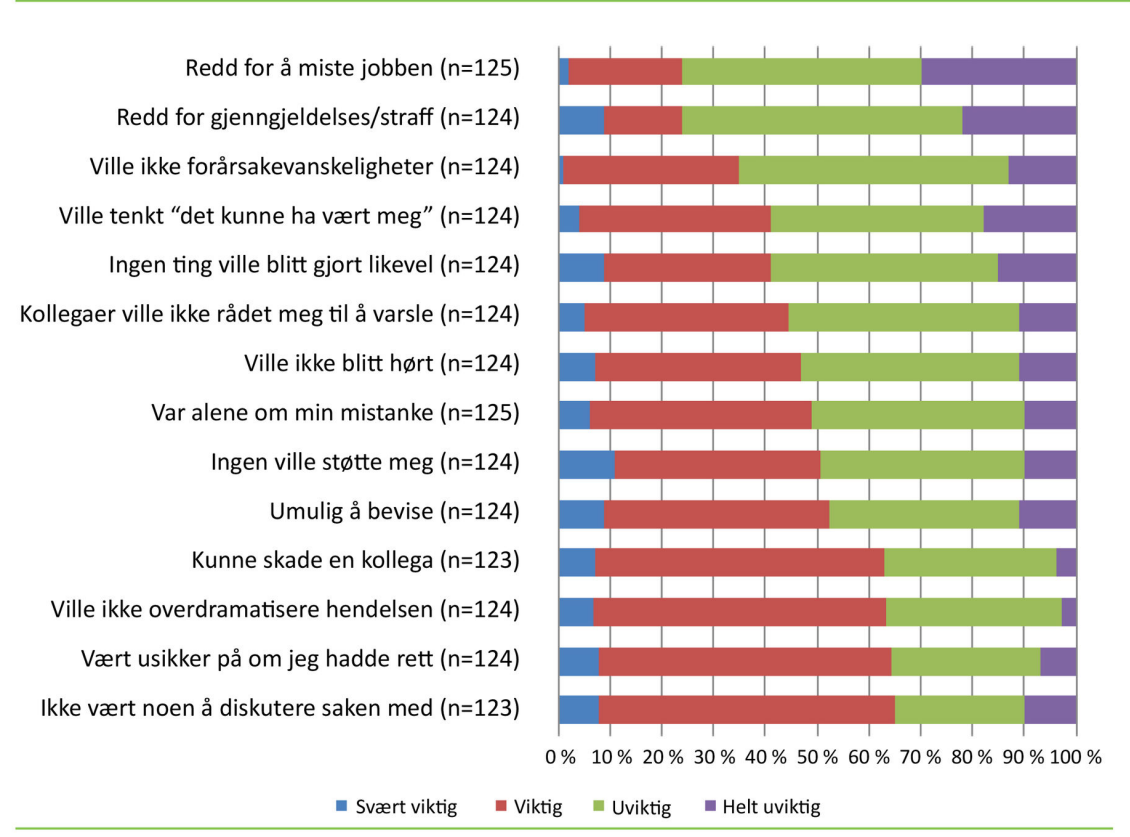

\section{DISKUSJON}

Hensikten med studien var å belyse faktorer som påvirker jordmødres og psykiatriske sykepleieres varsling av avvik. Resultatet viser at mange av informantene hadde vært $\mathrm{i}$ situasjoner der de hadde vurderte å varsle, men at de noen ganger hadde latt være. Informantene svarte at det først og fremst var viktig å unngå at pasienter skades, men også at de vurderte hensynet til seg selv, kollegaer og forhold i arbeidsmiljøet før de varslet.

\section{KLINISKE FEIL I PASIENTSIKKERHETSARBEIDET}

«Forbedre praksis / minimalisere skade for pasient» var den viktigste etiske begrunnelsen for å varsle - et forhold som oppfattes å være i tråd med nasjonalt pasientsikkerhetsarbeid, lovverk og yrkesetiske retningslinjer for sykepleiere $(4,5,7)$. Samtidig kan man spørre om hendelser som resulterer i påviselig skade, har høyest prioritet i pasientsikkerhetsarbeidet. Mer enn halvparten av informantene kjente ikke til retningslinjer for varsling av uetisk praksis. Det antyder at varsling av kliniske feil vurderes som overordnet varsling av uetisk praksis. Dette støttes av den kvalitative delen av studien, der informantene etterlyste mer oppmerksomhet på etiske forhold og varsling av uetisk praksis (17).

Det var flere psykiatriske sykepleiere enn jordmødre som varslet hendelser de hadde vært vitne til, og som kjente til prosedyrer for varsling av uetisk praksis. Flere psykiatriske sykepleiere enn jordmødre rangerte "forbedre praksis / minimalisere skade for pasient» lavest. En mulig forklaring er ulike holdninger i de to yrkesgruppene. Holdninger er en av faktorene som påvirker handling (23). På den andre siden påvirkes beslutning om å varsle av flere forhold enn holdning $(15,22-26)$.

\section{UKLARE RETNINGSLINJER GIR MANGLENDE RAPPORTERING}

En nederlandsk studie fant at holdningsskapende opplæring i pasientsikkerhetsarbeid førte til økt oppmerksomhet på avvik og større kompetanse til å identifisere og varsle dem. Dette var imidlertid ikke nok til å fylle gapet mellom intensjonen om å varsle, og det å faktisk gjøre det (26). En annen forklaring kan være at de psykiatriske sykepleierne har klarere retningslinjer og mer oppmerksomhet på varsling av uetiske handlinger, som for eksempel $\mathrm{i}$ tilknytning til tvang. Studier som viser at uklare retningslinjer kan føre til manglende rapportering, støtter opp om denne antakelsen $(22,24,25)$. 


\section{«Opplevd risiko for sanksjoner kan påvirke beslutningen om å varsle.»}

Pasientens autonomi - selvbestemmelse - fikk høy prioritet. Man kan spørre hvorfor autonomi løftes fram og får egenverdi, mens ivaretakelse av pasientens integritet og gjensidig respekt, som kan være en følge av autonomi, prioriteres lavere. Grunnen kan delvis være at sykepleierne prioriterte mellom flere svaralternativer, men det er likevel interessant at dette prioriteres så lavt. Det å bli møtt med respekt, er viktig når man er i et behandlingsløp. Offentlige meldinger påpeker at brukere i større grad skal involveres og ha innflytelse når de mottar helsehjelp. Mangel på respekt og medbestemmelse kan true retten til medvirkning (27).

\section{VURDERER KONSEKVENSER FøR VARSLING}

Til tross for høy prioritering av «forbedre praksis / minimalisere skade på pasient» vurderer spesialsykepleierne forhold i arbeidsmiljøet $f ø r$ de varsler. Nesten alle svarte at det er vanskelig å varsle avvik gjort av en kollega, og at de før varsling vil vurdere forhold som berører relasjonen til arbeidskollegaer (tabell 2). De prioriterte å følge anerkjente prosedyrer som «å snakke med de det gjelder» og å forsikre seg om at det «ikke ble inntatt en klandrende innstilling» til de involverte. Her er informantene på linje med helsemyndighetene. Hensikten med varsling er ikke å peke ut syndebukker og tildele skyld, men å $\emptyset$ ke pasientsikkerheten $(4,17,28)$.

Samtidig ser vi en tendens til at spesialsykepleierne ikke har tillit til at oppmerksomheten på pasientsikkerhet og læring av feil opprettholdes i praksis. Før de varslet, ville nesten alle informatene vurdere forhold som berører ivaretakelse av involverte kollegaer, mens en fjerdedel ville vurdere «faren for gjengjeldelse» og «faren for å miste jobben» (figur 1). At denne trusselen er reell, støttes av annen forskning $(12,13,18)$.

\section{ANSVARET PLASSERES HOS ENKELTINDIVIDET}

En unders $\varnothing$ kelse gjennomført av Norsk Sykepleierforbund, fant at 19 prosent av sykepleierne kjente til negative konsekvenser av avviksføring fra egen arbeidsplass, og at 13 prosent hadde opplevd negative reaksjoner fra ledelse eller kollegaer etter avviksmelding (30). Dette samsvarer med tendensen i denne studien. Opplevd risiko for sanksjoner kan påvirke beslutningen om å varsle. Basert på dette funnet kan man spørre om hvorvidt ansvaret for avvik og varsling i for stor grad plasseres hos enkeltindivider, mens det er mindre oppmerksomhet på kompliserte årsakssammenhenger og forhold som skyldes systemsvikt. Dersom dette er tilfelle, kan det bidra til å forklare hvorfor spesialsykepleierne så sterkt poengterte ivaretakelse av de involverte, og at de uttrykte empati med sine arbeidskollegaer og pekte på at «det kunne ha vært meg». Det kan også være med på å forklare hvorfor tre fjerdedeler av dem som ikke varslet, svarte at de burde ha gjort det, og at hver tiende av dem som hadde varslet, ikke ville varslet igjen.

\section{VIL IKKE OVERDRAMATISERE}

Tendensen støttes av studier som viser at sykepleiere som har vært involvert i avvik, har opplevd manglende støtte fra arbeidsmiljøet. Studiene fant også at sykepleierne var alene om å ta avgjørelsen om hvorvidt de skulle varsle eller ikke. Sykepleiere rapporterer også at de har vært utsatt for formelle eller uformelle sanksjoner fra ledelsen eller arbeidsmiljøet $(24,26,28)$. Det kan synes som om informantene kom i en lojalitetskonflikt dersom hensynet til pasienten, kollegaer og dem selv kom i konflikt.

Det virket også som at det var en vanskelig balansekunst å prioritere mellom de ulike hensynene. Denne antakelsen styrkes av at flere av dem som ikke hadde varslet, enn dem 
som hadde varslet, svarte «ville ikke forårsake trøbbel». Antakelsen styrkes også av at tre fjerdedeler av informantene svarte at det er viktig «ikke å overdramatisere hendelsen». Påstanden som fikk høyest skår som faktor som kan hindre varsling, var «ikke å ha noen å diskutere saken med» (figur 1). Dette antyder at avgjørelsen om å varsle baseres på komplekse vurderinger, og at valget er vanskelig. Man kan stille seg spørrende til hvorvidt det snakkes for lite om opplevelser i tilknytning til avvik, og hvorvidt det mangler åpenhet og aksept for at avvik forekommer.

\section{«Avgjørelsen om å varsle baseres på komplekse vurderinger.»}

Til tross for $\varnothing$ kt oppmerksomhet på utvikling av pasientsikkerhetskulturer $(1,4) \mathrm{er}$ resultatene fra denne studien fortsatt aktuelle. Det er begrenset med studier fra en norsk kontekst der forskerne prøver å forstå hvorfor helsepersonell unnlater å varsle. Det er viktig å belyse hva slags påvirkning psykososiale aspekter har på varsling, hvilken innflytelse et meldesystem og retningslinjer har for meldefrekvensen, og hvilke typer hendelser som varsles. Dette kan samlet bidra til økt forståelse for hvordan varsling er relatert til individuelle forutsetninger, arbeidsmiljøkontekst, avviksmeldesystem og ledelse.

\section{METODEKRITIKK}

Spørreskjemaet var delvis egenutviklet og ikke forhåndsvalidert, og spørsmål kan ha blitt misforstått eller svar feiltolket. Det er en styrke at flere av spørsmålene var prøvd ut i en pilotstudie, og at spørreskjemaet ble modifisert basert på denne studien. Vi fors $\emptyset$ kte å unngå uklarheter rundt begreper ved hjelp av informasjonsskrivet som fulgte skjemaet, og en forklarende ingress før spørsmålene. Liten spredning i materialet og lav missing i data kan tyde på at informantene har oppfattet spørsmålene, og at problemstillingene var kjente.

Egenrapportering av et fenomen behøver ikke få fram hele bildet. Informanten kan ha «glemt» situasjoner eller ønske at noe ikke skal komme fram. For eksempel kan ønsket om en positiv framstilling av egen yrkesgruppe påvirke informanter til å svare etter anerkjente oppfatninger. Avvik og varsling er sensitive temaer, og selv om kravet til anonymitet ble ivaretatt, kan det likevel være at noen unnlot å svare på enkelte spørsmål. For at det skulle være praktisk mulig å gjennomføre spørreundersøkelsen, utførte vi studien på et selektert utvalg. Vi innhentet heller ikke opplysninger om hvor mange som ble invitert til å delta.

Utvalget består av informanter fra ti ulike helseforetak, og det er likhetstrekk mellom utvalget og yrkesgruppene slik de er sammensatt i yrkeslivet. Det er flere kvinner enn menn, flere psykiatriske sykepleiere enn jordmødre, og flere mannlige psykiatriske sykepleiere enn mannlige jordmødre. Det er mulig at de spesialsykepleierne som har svart, er de med størst interesse for eller mest erfaring fra varsling.

Resultatet må tolkes i lys av at studien sier noe om disse spesialsykepleiernes prioriteringer og vurderinger uten at funnene kan generaliseres til å gjelde sykepleiere som gruppe, eller til å gjelde de valgte gruppene av spesialsykepleiere.

\section{KONKLUSJON}

Studien viser at deltakerne prioriterte pasientens rett til ikke å bli skadet høyt når de vurderte om de skulle varsle et avvik. De baserte beslutningen om å varsle eller ikke varsle på sammensatte vurderinger og var i stor grad påvirket av kulturelle og organisatoriske forhold. Det er viktig med en kultur for åpenhet om avvik og varsling samt støtte til de involverte uten tildeling av skyld eller fare for sanksjoner. I arbeidet med å $\varnothing$ ke varslingsfrekvensen er det lederens oppgave å fremme en arbeidskultur som aksepterer at 
det gjøres feil, som ønsker varsling velkommen, og som fokuserer på sammensatte årsaksfaktorer. Det er behov for mer kunnskap om hva som fremmer, og hva som hemmer, varsling. Samtidig er det viktig å drøfte retningen på pasientsikkerhetsarbeidet og etablere konsensus for hvilke hendelser som skal varsles, og hvilke som kan løses på andre måter. De som varsler, bør oppleve at varslingen har nytteverdi og fører til endring og forbedring for pasientene.

Takk til professor $\varnothing$ yvind Kirkevold for gode innspill og hjelp med de statistiske analysene.

Les relatert innspill: Åpenhet rundt varsling

\section{REFERANSER}

1. Skjellanger AG, Deilkås ET, Sørensen R, Advocaat-Vedvik J, Brudvik M, Schreiner M, Fredheim N, Longva KW, Austdal C, Lemser M, Nikolaisen J. Sluttrapport for pasientsikkerhetskampanjen «I trygge hender 24-7» 2011-2013. 2015. Tilgjengelig fra: http://www.kunnskapssenteret.no/publikasjoner/sluttrapport-for-pasientsikkerhetskampanjen-i-trygge-hender-24-7-2011-2013 (Nedlastet 01.10.2015).

2. Donaldson L. World Alliance for Patient Safety. WHO 2005 France: WHO. Tilgjenglig fra: http://www.who.int/patientsafety/en/brochure_final.pdf (Nedlastet 26.09.2016).

3. Vincent $C$, Aylin P, Franklin BD, Holmes A, Iskander S, Jacklin A, Moorthy K. Is health care getting safer? Bmj 2008;337:a2426. Doi: 10.1136/bmj.a2426.

4. Meld. St. nr 10 (2012-2013). God kvalitet - trygge tjenester. Kvalitet og pasientsikkerhet i helse- og omsorgstjenesten. Oslo: Helse- og omsorgsdepartementet. 2012.

5. Lovdata. Lov om spesialisthelsetjenesten. 2 juli 1999; nr. 61.

(Spesialisthelsetjenesteloven). Tilgjengelig fra: https://lovdata.no/dokument/NL/lov/1999-07-02-61

(Nedlastet 01.10.2015).

6. Lovdata. Forskrift om systematisk helse-, miljø- og sikkerhetsarbeid i virksomheter. 6. desember 1996; nr. 1127. (Internkontrollforskriften). Tilgjengelig fra: https://lovdata.no/dokument/SF/forskrift/1996-12-06-1127 (Nedlastet 01.10.2105).

7. Norsk Sykepleierforbund. Yrkesetiske retningslinjer for sykepleiere. 2014. Tilgjengelig fra: https://www.nsf.no/Content/1378906/Yyrkesetiske\%20retningslinjer.pdf (Nedlastet 10.01.2015).

8. Saunes IS, Svendsby PO, Mølstad K, Thesen J. Kartlegging av begrepet pasientsikkerhet (notat). Oslo: Nasjonalt kunnskapssenter for helsetjenesten. 2010. ISBN 978-82-8121-999-1.

9. Ahern K, McDonald A. The beliefs of nurses who were involved in a whistleblowing event. J Adv Nurs 2002;38:303-9.

10. Jackson D, Peters K, Andrew S, Edenborough M, Halcomb E, Luck L, Salamonson Y, Wilkes L. Understanding whistleblowing: qualitative insights from nurse whistleblowers. Journal of Advanced Nursing 2010;66:2194-201. Doi: 10.1111/j.1365-2648.2010.05365.x.

11. Vaartio H, Leino-Kilpi H, Salantera S, Suominen T. Nursing advocacy: how is it defined by patients and nurses, what does it involve and how is it experienced? Scand J Caring Sci 2006;20:282-92. Doi: 10.1111/j.1471-6712.2006.00406.x. 
12. Kirkehei IA, Lindahl K, og Tinnå M. Helsepersonell som har vært involvert i uønskede hendelser. Oslo: Nasjonalt kunnskapssenter for helsetjenesten (notat). Oslo:

Kunnskapssenteret. 2012.

13. Mesel T. Når noe går galt: fortellinger om skyld, skam og ansvar i helsetjenesten. Oslo: Cappelen Damm Akademisk. 2014.

14. Sirriyeh R, Lawton R, Gardner P, Armitage G. Coping with medical error: a systematic review of papers to assess the effects of involvement in medical errors on healthcare professionals' psychological well-being. Qual Saf Health Care 2010;19:43:8.

Doi:10.1136/qshc.2009.035253.

15. Black LM. Tragedy into policy: a quantitative study of nurses' attitudes toward patient advocacy activities. Am J Nurs 2011;111(6):26-35.

Doi:10.1097/01.NAJ.0000398537.06542.c0.

16. Peters K, Luck L, Hutchinson M, Wilkes L, Andrew S, Jackson D. The emotional sequelae of whistleblowing: findings from a qualitative study. J Clin Nurs 2011;20:2907-14.

Doi:10.1111/j.1365-2702.2011.03718.x.

17. Ulvund I, Dale KY, Ødegård, A. Skal - skal ikke. Jordmødre og psykiatriske sykepleieres erfaringer med varsling av avvik. Tidsskrift for Nordisk Helseforskning. 2015;11(2):86-96. Doi:http://dx.doi.org/10.7557/14.3714.

18. Sanghera IS, Franklin BD, Dhillon S. The attitudes and beliefs of healthcare professionals on the causes and reporting of medication errors in a UK Intensive care unit. Anesthesia 2007;62(1):53-61. Doi:10.1111/j.1365-2044.2006.04858.x.

19. Joolaee S, Hajibabaee F, Peyrovi H, Haghani H, Bahrani N. The relationship between incidence and report of medication errors and working conditions. International Nursing Review 2011;58:37-44. Doi: 10.1111/j.1466-7657.2010.00872.x.

20. Ulvund I, Vatne S. Varsling og mangel på varsling av kliniske feil og uetisk praksis (rapport). Molde: Møreforsking 2015. In press.

21. Firth-Cozens J, Firth, RA, Booth S. Attitudes to and experiences of reporting poor care. Clinical Governance: An International Journal 2001:8(4):331-6. Doi: 10.1108/14777270310499423.

22. Gifford ML, Anderson JE. Barriers and motivating factors in reporting incidents of assault in mental health care. J Am Psychiatr Nurses Assoc. 2010;5:288-98. Doi: $10.1177 / 1078390310384862$.

23. Ajzen I. Attitudes, personality and behaviour (2. utg.). Berkshire, Storbritannia: McGraw-Hill Education. 2005.

24. Evans SM, Berry JG, Smith BJ, Esterman A, Selim P, O'Shaughnessy J, DeWit M. Attitudes and barriers to incident reporting: a collaborative hospital study. Qual Saf Health Care 2006;15:39-43. Doi:10.1136/qshc.2004.012559.

25. Prang IW, Jelsness-Jørgensen LP. Should I report? A qualitative study of barriers to incident reporting among nurses working in nursing homes. Geriatr Nurs 2014;35:441-7. Doi:10.1016/j.gerinurse.2014.07.003. 
26. Jansma JD, Wagner C, Kate RW, Bijnen AB. Effects on incident reporting after educating residents in patient safety: a controlled study. BMC Health Serv Res 2011;335. Doi:

10.1186/1472-6963-11-335.

27. Helse- og omsorgsdepartementet. Og bedre skal det bli- Nasjonal strategi for kvalitetsforbedring i sosial- og helsetjenesten 2005-2015. Oslo: Sosial- og helsedirektoratet. 2005.

28. Jackson D, Peters K, Andrew S, Edenborough M, Halcomb L, Luck Y, Salamonson Y, Wilkes L. Understanding whistleblowing: qualitative insights from nurse whistleblowers. Journal of Advanced Nursing 2010;66:2194-201. Doi:10.1111/j.1365-2648.2010.05365.x.

29. Peters K, Luck L, Hutchinson M, Wilkes L, Andrew S, Jackson D. The emotional sequelae of whistleblowing: findings from a qualitative study. J Clin Nurs 2011;19-20:2907-14.

Doi:10.1111/j.1365-2702.2011.03718.x.

30. Hofstad E. Avvik stoppes og avvises. Sykepleien 2015;3:30-9. Tilgjengelig fra: https://sykepleien.no/2015/03/1-av-2-ser-ikke-nytten-av-melde (Nedlastet 12.09.2016). 